MARIAN KANIOR OSB

\title{
EREM SAN GIORGIO DI GARDA
}

\author{
POCZATTI ŻYCIA MONASTYCZNEGO \\ NA ROCCA DI GARDA
}

Kamedulski erem San Giorgio, w diecezji Werona, jest usytowany w szczególnie malowniczym zakątku Półwyspu Apenińskiego W oddali na północnej stronie horyzontu wznoszą się skaliste szczyty Alp, bielejące śniegiem przy dobrej widoczności. Na południowej stronie wysokiego wzgórza, na którym stoi klasztor, rozciagają się winnice $i$ ogrody oliwne, a dołem ciagnie się podłużne jezioro Garda. Samo wzgórze Rocca di Garda w ciagu historii przechodziło różne koleje losu. Za cesarstwa rzymskiego na obu sąsiadujących ze sobą wzniesieniach legiony rzymskie posiadały tu swóją warownię wojskowa (campus romanus). Poniżej obecnej pustelni, od strony południowej, wśród winnic, widnieją ruiny potężnego klasztoru św. Columbana, fundacji opactwa Bobbio, założonego przez mnicha irlandzkiego, św. Colombana Młodszego, jeszcze przed wędrówką ludów.Według miejscowej tradycji mnisi iroszkoccy z klasztoru św. Columbana wprowadzili znajomość uprawy drzewa oliwkowego w Północnej częśći Italii. Oliwa służyła wówczas do celów sakralnych. Mnisi iroszkoccy żyli tutaj do czasów karolińskich. Jeszcze dziś stoją ruiny tego opactwa, a dobra użytkowali właściciele (teatyni, kamelduli) Rocca di Garda. W okresie średniowiecza na wzniesieniu, gdzie znajduje się erem kamedulski, postawiono w wieku XI kościół romański pod wezwaniem św. Jerzego, który jeszcze istniał, gdy przybyli na tę górę około $1540 \mathrm{r}$. teatyni. Członkowie tego zakonu, założenego przez św. Gaetana z Tieny i Caraffę, biskupa Brindizi, dla reformy kleru diecezjalnego, zbudowali tu kościół i założyli klasztor, istniejący do połowy XVII wieku. Teatyni usunęli się z tego miejsca w 1657 r. z powodu częstych napadów rabunkowych ${ }^{1}$.

PIERWSI KAMEDULI NA ROCCA DI GARDA

Już w kilka lat po odejściu teatynów, bo w 1663 r., przybyli na to miejsce mnisi eremici z eremu kamedulskiego Monte Rua (Padwa), kongregacji kame-

${ }^{1}$ Informacja br. Romana Malaczewskiego OSB Cam. 
dułów-eremitów Monte Corona. Ta kongregacja powstała w wyniku reformy zakonn kamedulskiego, dokonanej przez św. Pawła Giustinianiego, generalnego przeora eremu Monte Corona.

Założona w 1520 r. przez niego kongregacja o nazwie Towarzystwo św. Romualda, przez kilka lat utrzymywała pewną zależność od Camaldoli. Dopiero w 1525 r. przekształciła się w całkowicie niezależna, dobrze zorganizowaną kongregację. Jako dom główny kongregacja obrała sobie erem Monte Corona, koło Perugii i stąd jej oficjalna nazwa brzmi Kongregacja Pustelników Kamedułów Monte Corona ${ }^{2}$. Cechą charakterystyczną nowej kongregacji było prowadzenie bardzo surowego życia pustelniczego w zamkniętych eremach $\mathrm{z}$ wykluczeniem klasztorów i jakiejkolwiek działalności zewnętrznej. Reforma zatem zrywała z dotychczasową tradycją tegoż zakonu, sięgającą czasów samego św. Romualda, przyjmującą zarówno życie cenobityczne, jak i pustelnicze, a to ostatnie jako dojrzały owoc życia monastycznego. Natomiast charyzmat św. Romualda obejmował zarówno klasztor jak i pustelnię. Sam św. Romuald miał zamiar podjaćc pracę misyjną na Węgrzech, chociaż do tego nie doszło. Do pracy misyjnej wysłał swoich uczniów Jana i Benedykta, późniejszych pierwszych polskich męczenników. Pracę misyjną prowadził na Węgrzech i w Prusach, św. Bruno z Kwerfurtu. W Cuxa, w Hiszpanii, gdzie św. Romuald spędził około 10 lat, istniało zarówno życie eremickie, jak i cenobityczne i ten styl życia św. Romuald przeszczepił do Italii. Tradycja monastyczna z czasów św. Romualda, jak i późniejsza, obok życia pustelniczego obejmowała również działalność duszpasterską jak i pracę naukowa. Przykładem tego mogą być dzieła Gwidona z Arezzo (990-1050) czy kameduły Gracjana. Niemniej nowa kongregacja okazała się bardzo prężna. W krótkim czasie jej mnisi zaludnili liczne eremy nie tylko w Italii, ale także w Hiszpanii, na Węgrzech i w Królestwie Polskim.

Początki eremu kamedulskiego na Rocca di Garda wiążą się z osobą fundatora, szlachcica z Padwy, ks. kanonika Jana Chrzciciela Dotti, który wstapił w 1661 r. do eremu Monte Rua i cały swój majątek przeznaczył na fundacje nowego eremu kamedulskiego na Rocca di Garda. Dzięki tej donacji przystąpiono do budowy eremu. Już w 1663 r. przybyli na wzgórze Monte San Giorgio dwaj mnisi z eremu Monte Rua: Bazyli i Józef i pod ich kierownictwem rozpoczęto prace związane $\mathrm{z}$ budową zabudowań, wedhug planu przyjętego $\mathrm{w}$ tej kongregacji, a więc kościoła, domków eremickich, zabudowań wspólnego użytku itd. W 1672 r. przeorat św. Jerzego na Rocca di Garda zaludnił konwent eremicki z przeorem Odonem z eremu Monte Rua. Dzięki pomocy materialnej drugiego dobroczyńcy, prawdopodobnie brata przeora Odona, Alvise di Beccelli, prace budowlane trwały nadal przez drugą połowę XVII wieku, zakończone w $1704 \mathrm{r}$. budową kościoła.

${ }^{2}$ Św. P i otr D a m i a n i, Żywot świętego Romualda, przekl. O. J. B o t o r, Warszawa 1991, s. 7 . 
KOŚCIÓ£ I BUDYNKI EREMU S. GIORGIO NA ROCCA DI GARDA

Istniejący do czasów obecnych kościół pod wezwaniem św. Jerzego, orientowany na wschód, jest prostokątną bryłą, $\mathrm{z}$ typową dla Włoch wieżądzwonnica. Cały wystrój kościoła ma praktyczne zastosowanie dla społeczności eremickiej. Nawa główna jest przegrodzona barokowym ołtarzem, za którym jest usytuowany chór mniszy. Do ołtarza prowadza schody marmurowe o kolorze jasnego brazzu. Nad mensą ołtarzowa, pomiędzy kolumnani $z$ jasno-brązowego marmuru, zakończonymi białymi głowicami, wznosi się tabernakulum, wykonane z marmuru o kompozycji koloru zielonego i jasno-brązowego (kształt i wystrój barokowy), a nad nim obraz patrona kościoła, św. Jerzego w zbroi, z włócznią w jednej ręce, a drugą trzymającego swego konia. Nad wejściem do chóru po lewej stronie stoi gipsowa postać św. Benedykta, trzymającego pastorał $w$ jednej ręce, a w drugiej regułę. Symetrycznie po prawej stronie stoi figura św. Romualda z podobizną kościoła i klasztoru (symbol założyciela, czy reformatora zakonu). W usytuowanym za ołtarzem chórze mniszym znajdują się stalle o skromnym wystroju. Chór oświetla duże okno, znajdujące się w zachodniej ścianie kościoła. Zarówno to okno jak i pozostałe okna w kościele sa wykonane $\mathrm{z}$ artystycznego szkła - zielonkawe, okragłe gomółki sq̨ oprawione w ołów. Obecnie na tylnej części głównego ołtarza jest zawieszony drewniany krzyż z czarną postacią Ukrzyżowanego Zbawcy.W górnej części tego wystroju znajduje się mały okragły obraz Świętej Trójcy malarzy rumuńskich: Florin

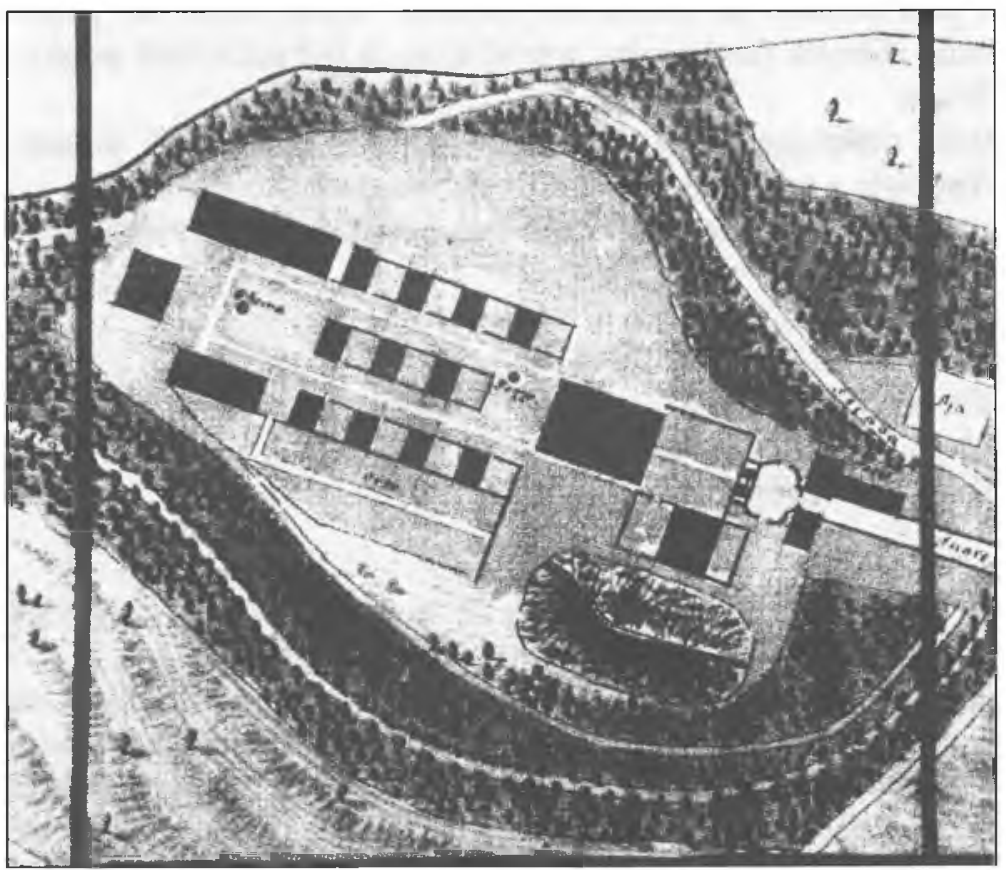

1. Plan eremu stan z roku 1810 (przed kasatą Napoleona). 
i Christan Ungoreom. Ściany chóru zdobią dwa inne obrazy tychże malarzy: Zmartwychwstały Chrystus wśród dusz w otchłani i Przemienie Pânískie na górze Tabor.

Ściany nawy głównej również do wysokości kilku metrów pokrywają stalle o podobnym wystroju i rzeźbie co stalle mnisze. Do drewnianej boazerii przylegają drewniane, niewielkie ławki. Kościół obejmuje jeszcze kaplice powięcone NMP Niepokalanie Poczętej, św. Józefowi, św. Benedyktowi i św. Romualdowi. W tej ostatniej znajduje się w ołtarzu obraz Palmo Giovanniego, namalowany specjalnie dla tego klasztoru oraz stylowe obrazy drogi krzyżowej. Kaplica św. Józefa była przeznaczona dla braci. Ściany tych kaplic są pokryte boazerią o podobnym stylu co nawa główna, $\mathrm{z}$ tą różnicą że zamiast siedzeń odosobnionych, jak w stallach, czy w nawie głównej, biegnie prosta ławka wzdłuż ściany, połączona z rzeźbioną boazerią. Ten styl dekoracyjny ścian przyjęty został we wszystkich trzech kaplicach. Posadzkę kościoła oraz wspomnianych stall stanowią płytki marmurowe biało-brązowe. Należy podkreślić, że kościół posiada centralne ogrzewanie na ropę, założone w latach 1994/95.

Pierwotne zabudowania klasztorne przeoratu kamedulskiego S. Giorgio obejmowały 12 domków-eremów o jednakowej konstrukcji budowlanej. Według przyjętego w kongregacji stylu budowlanego, wewnątrz, pośrodku każdego domku biegnie dhugi korytarz, a boczne cele dostosowane są do eremickiego życia: kaplica, sypialnia, pracownia i podręczny magazyn. Poszczególne domki oddzielone są od siebie małym, kwadratowym ogródkiem. Osiem domków było usytuowanych wokół wewnętrznego ogrodu, tworzącego typowy dla klasztorów włoskich wirydarz. Trzy pozostałe domki stanęły pośrodku tego wirydarza, a ostatni przy wejściu do eremu dla furtiana. Warto dodać, że poszczególne domki miały różnych fundatorów, wśród których był także król polski Jan Kazimierz Waza.

Mnisi realizując zamierzenia fundatorów wybudowali jeszcze cztery większe budowle z przeznaczeniem do wspólnego użytku:

1. Kuchnia, refektarz i tristeca na wspólne posiłki w ciągu niektórych dni (12 razy) w roku,

2. Biblioteka, archiwum, magazyn, pralnia,

3. Dom dla braci i infirmeria,

4. Dom dla gości, mieszkanie ekonoma i warsztaty rzemieślnicze.

Całość posiadłości otoczono murem kamiennym, który prawie w całości zachował się do czasów obecnych.

\section{EREM S. GIORGIO W OKRESIE WALK NAPOLEOŃSKICH}

Kameduli-eremici z kogregacji Monte-Corona prowadzili w tutejszym eremie swoje życie modlitwy, pracy i surowej ascezy do początku wieku XIX, tj. do wojen napoleońskich. Nowy władca Italii, Napoleon, w swej akcji sekularyzacyjnej klasztorów kontemplacyjnych na podbitych przez siebie terenach, zlikwidował także erem kamedulski S. Gregorio di Garda. Po usunięciu mni- 


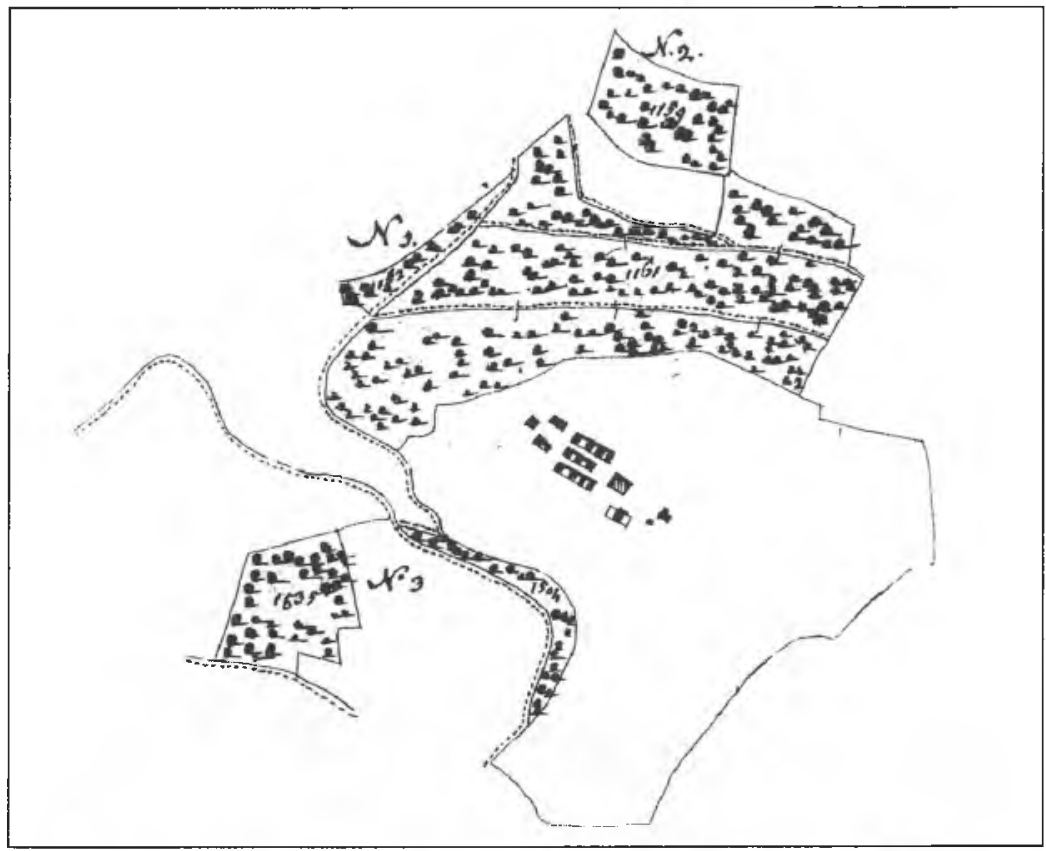

2. Mapa geodezyjna eremu i przylegających terenów z początku XVIII w.

chów, bibliotekę i archiwum przewieziono do Werony, gdzie stanowi obecnie poważny zasób biblioteki wojewódzkiej. Oczywiście argenteria kościelne rozkradziono. Natomiast cała posiadłość wraz zabudowaniami, lasem, ogrodami itd. przeszła w ręce rodziny hrabiowskiej Buri, z sassiedniego Bardolina. Wypada tu dodać, że budynki wyceniono jak materiał budowlany. Nowi użytkownicy, pragnąc dostosować ogrody klasztorne dla celów użytkowych zburzyli trzy domki-cele, znajdujące się pośrodku wirydarza.

\section{POWRÓT KAMEDUŁÓW NA ROCCA DI GARDA}

Dzięki nowej sytacji politycznej mnisi mogli wrócić do swojej posiadłości dopiero w 1885 r. Wskutek starań ówczesnego biskupa Werony, Alojzego kard. Canossy, rodzina Buri przekazała posiadłości klasztorne prawowitym właścielom i kameduli z eremu Monte Rua, po dokonaniu nieodzownych remontów w zrujnowanej pustelni, podjęli w roku 1885 życie eremickie. Ich nowa obecność w eremie S. Giorgio di Garda trwała do lat sześćdziesiątych dwudziestego wieku. Warto zaznaczyć, że tu żyli życiem eremickim także Polacy. Potwierdzają to groby, w liczbie ośmiu, znajdujące się na eremickim cmentarzu ${ }^{3}$.

${ }^{3}$ Są to imiona mnnichów - Polaków: br. Jakub z Jeruzal * 18 VII $1877+22$ V 1930; o. Maurycy z Kęt * 2II 1861 † 10 IV 1934; o. Aleksander z Lan * 5 XII 1873 + 17 XI 1936; o. Robert Rozdzień * 26 I $1862+8$ VIII 1940; o. Leon z Rudnika * 31 XII $1863 \uparrow 28$ VIII 1940; o. Leonard z Rącznej * 19 X 1891 + 19 XII 1942; o. Placyd z Trzebiny Kozińskie * 16 IX 1870 † 31 I 1958, br. Emilian z Międzyrzecza * 15 III 1905 † 7 I 1991. 
NOWA FORMA ŻYCIA KAMEDULSKIEGO W EREMIE S. GIORGIO ROCCA DI GARDA.

W roku 1963 kongregacja kamedulska Monte Corona, z powodu braku zakonników do prowadzenia normalnego życia mniszego sprzedała cała posiadłość człowiekowi świeckiemu, właścicielowi koncernu hotelowego. Gdy się o tej transakcji dowiedział biskup Werony, Nicoria Atylio, unieważnił umowę i korzystając $z$ prawa pierwokupu nabył budynki i majątek klasztorny dla diecezji. $Z$ kolei kuria diecezjalna w Weronie postanowiła wykorzystać przejęte bu-

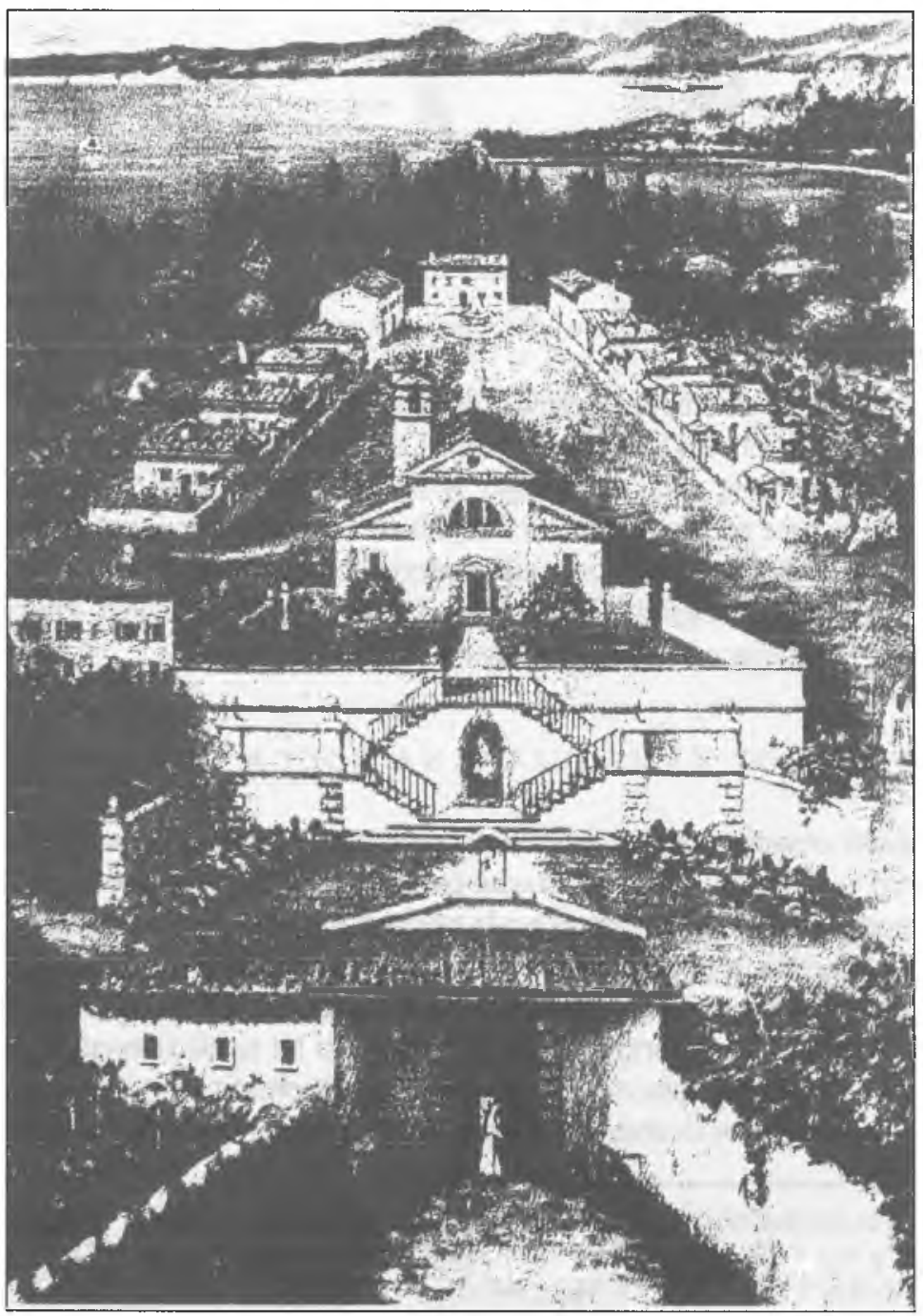

3. Ogólny widok zabudowań eremu S. Giorgio (stan obecny). 
dynki klasztorne na diecezjalny ośrodek krzewienia duchowości chrześcijańskiej, który tu istniał około dziesięciu lat Przy tej okazji dokonano adaptacji wnętrz istniejących zabudowań, bez porozumienia się z poprzednimi użytkownikami, kamedułami z Monte Corona.

Jednakże wyjątkowy urok miejsca, wielowiekowa tradycja, odosobnnienie itd. pociagnęły nowych kandydatów do opuszczonego eremu. Tym razem zadaniem odnowy życia kamedulskiego na Rocca di Garda zajęła się kongregacja kamedulska reguły św. Benedykta, która ma swój główny dom w Camaldoli, koło Arezzo, założony jeszcze przez św. Romualda w latach 1012-1024 $4^{4}$. Kongregacja kamedułów zaczyna oficjalnie swoje istnienie od bł. Rudolfa IV, przeora eremu Camaldoli. Wybrany w 1074 r. przeorem Camaldoli przyłączył do eremu liczne pustelnie, opactwa i posiadłości. ${ }^{5}$ Dla tej organizacji opracował konstytucje i od ich ogłoszenia można mówić o zakonie kamedułów, który nadal pozostawal w rodzinie zakonu benedyktyńskiego. Okresem rozkwitu tej kongregacji był wiek XI do XIV. Po tym okresie nastapiło rozluźnienie obserwy zakonnej, jak w większości klasztorów, z powodu powstałego zwyczaju mianowania opatów z zewnątrz. Opaci komendatariusze, najczęściej spoza zakonników (kardynałowie, biskupi, a nawet ludzie świeccy) dbali o własne dochody a nie o dobro klasztoru. Celem zapoczątkowania odnowy życia mniszego między innymi kapituła generalna w 1513 r. wprowadziła trzechletni okres kadencji opatów. Kongregacja przetrwała wszystkie burze historyczne. Bullą Inter Religiosos coetus z 5 VII 1935 r. Stolica Apostolska przyłączyła do kongregacji Camaldoli, (nie znosząc) powstałą w XVII wieku kongregację św. Michała z Murano. Powstała w ten sposób aktualna kongregacja nosi nazwę Kongregacji Kamedułów św. Benedykta i jest członkiem konfederacji benedyktyńskiej. Jej centrum jest tysiącletni erem Camaldoli. Obecnie obejmuje pięć eremów i cztery klasztory ${ }^{6}$.

Po wielu wzajemnych naradach i konferencjach między kongregacją kamedulską reguły św. Benedykta, a ordynariuszem i kurią diecezjalną w Weronie ostatecznie kongregacja Camaldoli podjęła się dzieła odnowy życia kamedulskiego na Rocca di Garda. Głównymi inspiratorami tego przedsięwzięcia byli o. Jerzy Botor, mnich Camaldoli, przełożony małej wspólnoty w Torra (diecezja Trydent) oraz jego współbrat z Camaldoli, br. Jan Dal Piaz. W wyniku tych zabiegów przybyła w latach dziewięćdziesiątych na Rocca di Garda mała wspólnota kamedulska złożona $\mathrm{z}$ czterech mnichów z opactwa Camaldoli: o. Jerzy Botor, przeor, br. Jan Dal Piaz, br. Gulio Rigamonti, o. Franco Mosconi i mnicha czasowego Romana Malaczewskiego ${ }^{7}$. Przed małym, ale prężnym zespołem mniszym stanęło trudne zadanie nie tylko rozpoczęcia eremickiego życia, ale dokonania generalnego remontu zapuszczonych zabudowań. Uroczyste otwarcie

${ }^{4}$ Giuseppe V e d o v a to, Camaldoli e la sua congregazione dalle origini al. 1184. Storia e dokumentazione, Cesena 1994, s. 21 i ns.

${ }^{5}$ Cécile $\mathrm{C} \mathrm{a}$ b y, De l'érémitisme rural au monachisme urbain. Les camaldules en Italie à la fin du moyen age, Rome 1999, s.75 i ns.

${ }^{6}$ Lino Vilgilu c c i, Camaldoli, Itinerario di storia e di spiritualità., Camaldoli 1988 , s.158 ins.

${ }^{7}$ Informacja o.przeora Jerzego Botora OSB Cam. 
pustelni nastąpiło 23 kwietnia 1993 r. z udziałem biskupa Werony Nicora Atylio i jego biskupa pomocniczego. W tym dniu miała także miejsce pierwsza, wieczysta profesja br. Romana Malaczewskiego. Wkrótce zgłosiły się nowe powołania. Obecnie wspólnota mnisza eremu Rocca di Garda składa się z siedmiu profesów wieczystych (jeden już zmarł), jednego profesa czasowego (Natale Bresciamini), jednego nowicjusza (Zenon Ferrari) i czterech postulantów. Czasowo przebywa także jeden mnich - Polak, Robert Laskarzewski, kameduła z kongregacji Monte Corona.

\section{DZIEŃ MNISZY W EREMIE S. GIORGIO}

$\mathrm{Na}$ codzienne zajęcia tej wspólnoty monastycznej składa się modlitwa, praca naukowa, i praca fizyczna. Zgodnie z regułą św. Benedykta modlitwa chórowa należy do obowiązków podstawowych mnicha. Toteż mnisi tego eremu gromadzą się codziennie pięć razy, w chórze kościelnym. Codzienny porządek zajęć chórowych jest następujący:

godz. 6.00 - Godzina czytań (Ufficio delle letture)

godz. 7.30 - Laudesy (Lodi)

godz. 12.40 - Godzina dzienna (Ora media)

godz. 18.30 - Nieszpory wraz ze mszą św. (Vespri ed Eucarestia)

Ten porządek oficjum ulega pewnej modyfikacji w sobotnie popołudnia i niedziele.

Większość oficjum chórowego, oczywiście w języku włoskim, jest śpiewana i to na stojąco. Tylko w ferialnym oficjum porannym „Ufficio delle letture" (godzina czytań) psalmy są częściowo recytowane na przemian przez dwa chóry, a częściowo śpiewane. Wypada jeszcze wspomnieć, że śpiew psalmów jest wykonywany naprzemian przez dwa chóry, lecz niekiedy jest wtrącany śpiew solowy, a chór powtarza tylko antyfonę, lub część psalmu, jako refren. Kongregacja nie ma w użyciu opracowanego, pełnego, własnego, kalendarza liturgicznego. Tylko największe uroczystości zakonne kongregacji jak: Boże Narodzenie, Epifania, Wielkanoc, uroczystość św. Romualda itd. posiadają pełne ordo liturgiczne dla godziny czytań ${ }^{8}$, co pozwala na dostosowanie śpiewu do liturgii dnia. Dla celów liturgicznego śpiewu została opracowana i wydana dwukrotnie -- księga modlitw: Psalterium monasticum ${ }^{9}$, która zawiera zestawienie hymnów i psalmów wraz z melodiami. Całość opracował zespół liturgiczny kongregacji według posoborowych wskazań liturgicznych. Gównym autorem melodii i wielu tekstów hymnów był Tomasz Matus, kameduła, amerykanin polskiego pochodzenia. Melodie zostały przejęte bądź to $\mathrm{z}$ dawnych ksiąg liturgicznych kongregacji. Na wielkie uroczystości dla starych hymnów zachowano

${ }^{8}$ Ufficio delle letture. Celebrazione nei giorni di festa e solennità (commune e proprio), Sacro Eremo e Monasterio di Camaldoli 2000.

${ }^{9}$ Communità dei monaci di Camaldoli, Salterio monastico canto e preghiera a cura di Thomas Matus, Bologna 1999. 
łacinę. Większość hymnów i antyfon stanowią teksty śpiewane powszechnie w Kościele rzymsko-katolickim. Wiele jest nowych hymnów z własnymi tekstami i melodiami. Ramowe opracowanie rozkładu hymnów i psalmów na pozostałe godziny liturgiczne (laudesy, godzina dzienna, nieszpory) na uroczystości, święta, wspomnienia świętych oraz dni ferialne. W kongregacji obowiązuje dwutygodniowy podział psalmów. Całość opracowanego materiału przesyłano jeszcze do opactwa benedyktyńskiego w Solemnes do ostatecznego wygładzenia melodii ${ }^{10}$. Czytania liturgiczne używane podczas oficjum Liturgia delle ore. L'Ora dell Ascolto, Lezionario biblico-patristico a ciclo bieniale per l ufficio delle letture opracował dla wszystkich gałęzi monastycznych Italii zespół „Unione monastica italiana"ll Te ogólno-monastyczne czytania są dostosowane do kalendarza liturgicznego $\mathrm{z}$ podziałem na lata parzyste i nieparzyste oraz do lekcjonarza niedzielnego (rok A B i C).Teksty Pisma św. tak są podzielone w cytowanej ksiażce czytań liturgicznych, by całość Pisma św. była przeczytana w ciagu dwóch lat. Do tekstów Pisma św. są dostosowane komentarze Ojców Kościoła itd. ${ }^{12}$

Codzienną Służbę Bożą rozpoczynają mnisi o godzinie 6 rano modlitwą liturgiczną zwaną godzina czytan (ufficio delle letture). Na tę godzinę wchodzi w pierwszej części - psalm inwitatoryjny $z$ antyfoną jako refrenem, dwa inne psalmy wraz z antyfonami oraz lektura Pisma Św. W okresie od Wielkanocy do Zielonych Świąt czytania tam zawarte brane są z Nowego Testamentu. W pozostałym okresie roku liturgicznego są czytane urywki ze Starego Testamentu. Po tej lekturze następuje w chórze dosyć długa chwila ciszy, celem refleksji na Słowem Bożym. Na drugą część tej godziny liturgicznej składa się śpiew jednego lub dwóch psalmów $\mathrm{z}$ antyfonami (zależnie od długości psalmu) i lektura z Ojców Kościoła. Są to komentarze do przeczytanego urywku Pisma Św. w pierwszym czytaniu. Po zakończeniu lektury znów następuje dłuższa cisza w chórze. Godzinę czytań kończy śpiew części Psalmu 118 (bez antyfony), jakiś krótki komentarz z dnia liturgicznego i modlitwa. Po zakończeniu tej modlitwy chórowej mnisi mają czas przeznaczony na indywidualne ćwiczenie duchowe, a zarazem bardzo starą praktykę ascetyczną, zwaną Lectio divina.

O godzinie 7,30 znów mnisi gromadzą się w chórze na modlitwę liturgiczną zwaną Laudesy (Lodi), na którą się składa śpiew hymnu, trzech psalmów wraz $\mathrm{z}$ antyfonami, czytanie przez prowadzącego modlitwy (hebdomadariusz) do ewangelii $z$ dnia. Poczem znów następuje dłuższa cisza w chórze i śpiew kantyku Zachariasza wraz z antyfona. Ta ostatnia jest zmienna w zależności od kalendarza liturgicznego. Na wielkie uroczystości są to antyfony stare, a sam kantyk jest śpiewany po łacinie. Laudesy kończą się krótkim komentarzem prowadzącego modlitwy do urywku ewangelii, wspólna recytacja lub śpiew modlitwy Pańskiej (Ojcze Nasz) i modlitwa dnia. Na zakończenie laudesów śpiewa się antyfony ku czci świętych lub i innych, dostosowanych do liturgii dnia.

\footnotetext{
${ }^{10}$ Informacja br. Natale Bresciamini OSB Cam.

${ }^{11}$ Aprobata Św. Kongregacji Obrzędów i Bożego Kultu z 15 kwietnia 1977 r.

${ }^{12}$ Informacja o. Przeora Jerzego Botora OSB Cam.
} 
Podobny przebieg ma godzina chórowa zwana godziną dnia (przed obiadem), na którą się składają: śpiew hymnu, jednego lub dwóch psalmów z antyfona, czytanie przez prowadzącego modlitwy urywku ewangelii i jego krótki komentarz, śpiew krótkiego odcinka Psalmu 118 i modlitwa dnia. Hymn jest dostosowany do kalendarza dnia. Godzinę kończy śpiew antyfony ku czci św. Romualda. Teksty tych antyfon pochodza jeszcze z pism św. Piotra Damiana.

Centrum liturgiczne dnia stanowią nieszpory, połączone w ciągu tygodnia ze mszą św. Tę część oficjum liturgicznego rozpoczyna śpiew hymnu, dostosowanego do liturgii dnia, np. hymn na uroczystości NMP. Po jego zakończeniu celebrans (ubrany naturalnie $\mathrm{w}$ ornat) rozpoczyna mszę św. krótkim wprowadzeniem w liturgię dnia i aktem pokuty, poczem stojący w chórze pozotali koncelebransi i mnisi podejmuja śpiew trzech psalmów wraz antyfonami. Dalsza część mszy św. przebiega normalnie. Pierwsze czytanie mszalne odczytuje któryś z mnichów lub z uczestniczących wiernych. Śpiewy lekcyjne są śpiewane przez lektora i pozostałych uczetników mszy św. Po ewangelii, odczytanej z któregoś z koncelebransów, główny koncelebrans, lub kolejno któryś z mnichów, nowicjuszy, czy nawet postulantów komentuje przeczytany tekst Pisma Św. Po tym komentarzu następuje chwila ciszy, po której główny koncelebrans kontynuuje liturgię mszy św. Niektóre części mszalne są śpiewane (sanctus, ojcze nasz, Baranku Boży). Po przyjęciu Komunii św. przez głównego celebransa i koncelebransów następuje Komunia św. pod dwiema postaciami - przez zanurzenie - pozostałych członków chóru oraz wiernych, zgromadzonych w nawie głównej kościoła. Warto tu wspomnieć, że w tygodniu zawsze jest pewna grupa wiernych, uczestniczących we mszy św., Po Komunii św. - w ramach liturgii nieszporów następuje śpiew kantyku magnificat wraz z odpowiednią antyfona, dostosowaną do kalendarza liturgicznego, modlitwa i błogosławieństwo wiernych. Końcowym akordem liturgii mszy św. połączonej $\mathrm{z}$ nieszporami jest śpiew antyfony ku czci NMP.

W niedziele msze św są sprawowane przed południem o godzinie 11 . Niedzielna liturgia mszy św. jest oczywiście bardziej urozmaicona przez śpiew koncelebransów i chóru mniszego na przemian lub wraz $\mathrm{z}$ wiernymi. Czasem nawet przybywa tu chór z jakiejś parafii. Na niedzielne śpiewy mszalne składaja się śpiewy: psalm na wejście, akt pokuty, gloria, psalm-responsorium, sanktus, ojcze nasz, hymn pokomunijny, i śpiew końcowy. Oczywiście również w bardziej uroczysty sposób są sprawowane partie należące do koncelebransa (śpiewana prefacja, okadzanie) i homilia na temat przeczytanych tekstów mszalnych. Wypada tu dodać, że w niedzielę we mszy św. uczestniczy dosyć dużo wiernych przyjeżdżających na górę di Rocca samochodami nawet $z$ odleglejszych okolic.

Liturgię niedzielną kończą uroczyste nieszpory, śpiewane przez mnichów kamedulskich wraz $\mathrm{z}$ wiernymi, zebranymi w nawie kościoła. Po zasypaniu kadzidła do kadzielnicy stojącej przed ołtarzem soborowym chór rozpoczyna śpiew hymnu inwitatoryjnego, a nastepnie trzech psalmów $\mathrm{z}$ antyfonami. Oczywiście podczas śpiewu kantyku magnificat następuje okadzenie ołtarza, krzyża pasyjnego, stojących w chórze mnichów i wiernych w nawie głównej. Końcową modlitwę dnia - kompletę - odmawiają mnisi indywidualnie, zwykle w małej 
kaplicy wewnątrz eremu., gdzie również jest przechowywany w tabernakulum najświętszy Sakrament.

\section{CODZIENNA PRACA MNICHA KAMEDULY}

Modlitwa liturgiczna wprawdzie stanowi istotna fundamentalną część życia duchowego mnicha kamedulskiego, ale tylko część. Bardzo ważną rolę w rozwoju życia wewnętrznego stanowi także praca. Nie tylko ze względów życiowych, gdyż w obecnych warunkach ekonomicznych społeczństwa praca jest zwykle głównym środkiem utrzymania każdego człowieka. Dla mnicha praca jest także poważnym środkiem ascetycznym. Jest to przecież współpraca z samym Stwórcą w istnieniu wszechświata i rozwoju ludzkości. Praca pozwala człowiekowi rozwijać swoje uzdolnienia, jakimi go Bóg obdarzył, pokonywać napotykane przeszkody, co z kolei pogłębia osobowość, uszlachetnia uczucia, rozwija umysł. Dzięki wynikom swej pracy człowiek może służyć drugim, i tym samym zashugiwać sobie na nagrodę $w$ niebie, a już tu na ziemi praca daje człowiekowi dużo satysfakcji, gdyż jak mówi Pismo św. „więcej szczęścia jest w dawaniu niż w braniu" ${ }^{\text {"13 }}$. Toteż nic dziwnego, że św. Benedykt w swej regule stawia pracę jako nieodzowny warunek życia mniszego.

Bardzo pracochłonną dla mnichów eremu San Giorgio jest posiadłość ziemska, obejmująca oprócz kościoła i zabudowań klasztornych, winnice i ogrody oliwne. Toteż praca w ogrodzie oraz utrzymanie porządku wewnątrz eremu dominuje i będzie jeszcze dominować przez długi czas w zajęciach codziennych mnichów kamedulskich tego eremu. Przykład daje sam o. przeor Jerzy, którego często można widzieć $\mathrm{w}$ roboczym uniformie przy różnych pracach ogrodowych. Na razie mała wspólnota nie jest w stanie podołać wszystkim pracom, dlatego winnice oddano na pewien czas $w$ dzierżawę. Zachowano natomiast ogrody oliwne, gdyż te nie wymagają tak wielkiego nakładu kosztów i pracy co winnice. Oprócz starych drzew oliwkowych już w kilku miejscach posadzono młode drzewka oliwkowe. Należy tu podkreślić, że oliwa z oliwek eremu San Giorgio uzyskała bardzo wysoki test jakościowy ${ }^{14}$. W razie potrzeby wspólnota korzysta z pomocy ludzi świeckich. Do nich należy kucharka, która gotuje w tygodniu obiady dla mnichów i ich gościi. Natomiast śniadania i kolacje oraz pożywienie w niedzielę przygotowują sobie sami mnisi. W tym celu wyznaczane są dyżury. Ponieważ część jednego z budynków jest przeznaczona na dom gościnny, przygotowanie pokoi dla gości stanowi kolejny obowiazek pracy mniszej.Oprócz obowiazków, zwiazzanych z normalnym trybem życia w eremie, jego członkowie podejmują różne dodatkowe prace. Jeden $\mathrm{z}$ postulantów, br. Piotr, specjalista od farmacji, produkuje różne artykuły lecznicze i kosmetyczne, sprzedawane następnie $\mathrm{w}$ miejscowym sklepiku. Ostatnio inny postulant, br. Marco, wykonał dwie żelazne bramy: brama wejściowa i druga brama do po-

\footnotetext{
${ }^{13}$ Dz. Ap. 20, 35.

${ }^{14}$ Informacja br. Gulia Rigamonti OSB Cam.
} 


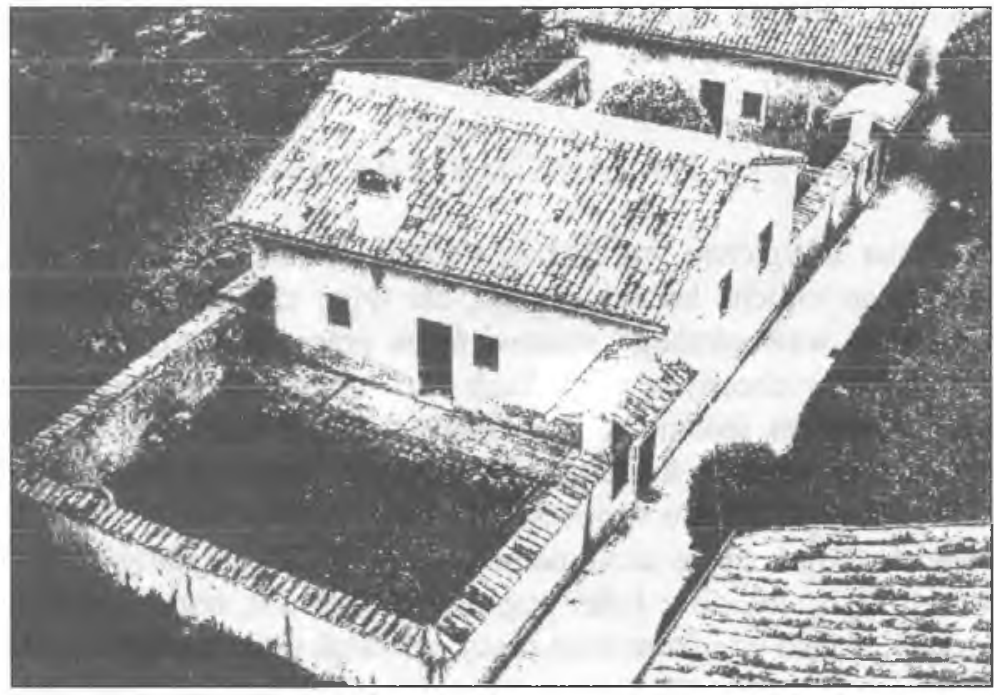

4. Jeden $\mathrm{z}$ domków kamedulskich stan aktualny

mieszczenia, gdzie się uzdatnia wodę pitna, z których każda mogłaby stanowić przedmiot egzaminu na tytuł mistrza w śrdniowiecznym cechu kowali.

\section{RÓŻNORODNOŚĆ KAMEDULSKICH ZAJÉĆ}

Mały ale ambitny konwent eremu S. Giorgo Rocca di Garda podejmuje różnorodne i odpowiedzialne obowiązki na zewnątrz. Br. Jan Dal Piaz jest wikariuszem generalnym kongregacji , kierownikiem odbudowy eremu i magistrem nowicjuszy. Podprzeor o. Franco Mosconi jest poszukiwanym rekolekcjonista dla księży, zakonów, seminariów. Nie nadąża za zamówieniami ${ }^{15}$. Inny z mnichów wieczystych, br. Lorentzo Saraceno, oprócz zajęć na uniwersytecie w Weronie, już od dłuższego czasu współpracuje nad krytycznym przygotowaniem do druku dzieł i pism św. Piotra Damiani ${ }^{16}$. Owocem tej pracy sa już dwa tomy tych dzieł. W przygotowaniu do druku jest już tom trzeci. Plan wydawniczy obejmuje osiem tomów. Tenże br. Lorentzo Saraceno wraz z drugim mnichem o. Franco Masconim prowadza w tutejszym eremie cotygodniowe, sobotnie spotkania biblijne dla ludzi świeckich, zainteresowanych Pismem św. W maju bieżącego roku br. Lorentzo brał udział w semianarium biblijnym w Centrum Życia Duchowego Księży Salwatorianów w Krakowie ${ }^{17}$. W różnych spotka-

${ }^{15}$ Informacja o. przeora Jerzego Botora OSB Cam.

${ }^{16}$ T. 1. Opere di Pier Damiani 1/1 - Pier D a m i a n i, Lettere (1-21) A cura di G. I. Gargone e N. D’Acunto; Traduzioni di A. Dindelli, L. Saraceno, S. Somogli, Città Nuova 2000; T. 2. Opere di Pier Damiani, 1-2 Pier D a m i a n i, Lettere ( 22-40) A cura di G.I. Gargano e N. D'Acunto; Traduzioni di A. Dincelli, L. Saraceno. C. Somogli; Revisione generale di L. Saraceno, Città Nuova 2001.

${ }^{17}$ Informacja br. Lorentzo Saraceni OSB Cam. 
niach naukowych, zwłaszcza biblijnych, bierze często udział o. przeor eremu S. Giorgio, Jerzy Botor.

Dla przybywajcych pielgrzymów - turystów do eremu kamedulskiego na Rocca di S. Giorgio jest prowadzony na furcie sklepik o dosyć szerokim asortamencie. Przede wszystkim przedmiotem sprzedaży są książki o tematyce religijnej, zwłaszcza związanej z duchowością i historia zakonu kamedulskiego. Dosyć dobrze sklepik jest zaopatrzony w różne przetwory na podłożu ziót. Wśród nich należy wymienić kilka rodzajów likierów, miejscowej produkcji oraz eremu Camaldoli, konfitury, oliwę z oliwek, grzyby itd. Szczególnym popytem wśród turystów cieszy się różnego gatunku miód. Spośród artykułów leczniczych i kosmetycznych na uwage zasługują także specjalne zioła $\mathrm{z}$ tutejszego eremu, różnego rodzaju ziołowe maści, balsamy, kremy, mydła, szampony, szminki , perfumy itd.

Ważnym działem w całokształcie działalności monastycznej eremu jest dom gościnny, do którego są przyjmowani nie tylko mężczyźni ale także kobiety. Oczywiście najczęściej ze skupienia korzystaja księża i klerycy. Ci ostatni przed święceniami, często całe kursy seminaryjne. Nie rzadkie są wypadki, że na kilkudniowe skupienie zgłaszają się pary małżeńskie, czy narzeczeni przed podjęciem ostatecznego zamiaru zawarcia małżeństwa. Gośćmi tego eremu bywają także siostry zakonne. Zwykle goście przyjeżdżają w poniedziałek i przebywają do piątku. Sobota jest dniem przygotowania pokoi gościnnych dla nowych gości.

Goście zwykle uczestniczą we wszystkich modlitwach liturgicznych w chórze. Natomiast posiłki spożywają osobno w refektarzu gości. Oczywiście wszystkich gości obowiązuje pewien rygor (silentium, zakaz palenia papierosów po korytarzach itd.). Na podkreślenia zasługuje fakt, że gościom nie wyznacza się taksy pieniężnej za pobyt w klasztorze. Przyjmuje się tylko dobrowolne ofiary. Ten styl obsługi gości jest przyjęty także w innych eremach kongregacji np. w Camaldoli. Do otwarcia się kamedułów na potrzeby wiernych zachęcał późniejszy papież Paweł VI, jeszcze jako Mrs. Montini, gdy był asystentem Katolickiej Młodzieży Akademickiej. Podobnie Jan Paweł II ponowił ten sam apel podczas wizyty eremu Fonte Avellana w 1982 r. z okazji tysiąclecia istnienia kongregacji. Podczas odwiedzin eremu Camaldoli w 1991 r. wystosował nawet specjalny list w tej sprawie, by eremy kamedulskie były miejscem spotkań, zarówno wierzących jak i ludzi nie związanych z Kościołem ${ }^{18}$.

\section{REFLEKSJE KONCOWE}

W przyszłym roku kameduli kongregacji eremityczno-cenobitycznej św. Benedykta będą obchodzić skromny jubileusz dziesięciolecia objęcia eremu S. Giorgio di Rocca. Każdy jubileusz stawia przed jubilatami obraz dotychczasowych osiagnięć i pewne plany na przyszłość. Mała społeczność eremu S.

${ }^{18}$ Informacja o. przeora Jerzego Botora OSB Cam. 
Giorgio di Rocca może być dumna z dotychczasowych wysiłków nad dostosowaniem klasztoru do wymogów stawianych obecnie przed zakonnikami, nawet tego rodzaju co kameduli. Głównie dzięki zabiegom br. Jana w oparciu o pomoc materialną eremu Camaldoli, biskupa Werony i licznych sponsorów w ciągu tego dziesięciolecia dokonano niezwykle dużo prac. Bardzo wielkim przedsięwzięciem było przeprowadzenie nowoczesnej kanalizacji całego obiektu, dzięki czemu ten problem jest rozwiązany na długie lata. Inną ważną sprawą był generalny remont ośmiu domków mniszych, domu nowicjatu, domu obejmującego kuchnię z chłodnią i magazynem, refektarz mniszy i refektarz dla gości oraz pokoje gościnne, a wreszcie domu gdzie mieści się kaplica i biblioteka. Podczas tych prac remontowych w wymienionych budynkach potrzebna była wymiana. posadzki, drzwi, okien, przewodów elektrycznych i urządzeń kanalizacyjnych oraz założenie centralnego ogrzewania. Na kościele i małych domkach mniszych uzupełniono dachówkę, na pozostałych budynkach położono nowe dachy. Bibliotekę wyposażono w metalowe, nowoczesne regały oraz trzeba było od nowa gromadzić książki. Obecnie zasób biblioteczny już liczy około 30 tysięcy woluminów i to ksiazzek niekiedy bardzo cennych jak encyklopedie, słowniki, albumy itd. Oczywiście większość zbioru stanowią książki z zakresu historii i duchowości mniszej, ale nie tylko. Ponieważ przeorem jest Polak na półkach bibliotecznych znajdują także książki w języku polskim jak: wszystkie dzieła J. Długosza, Wielki Słownik Królestwa Polskiego (15 tomów), Polski Słownik Biograficzny (od 1 tomu do ostatnich pozycji), Monumenta Poloniae Vaticana (6 tomów), Pomniki Dziejowe Polski i inne. Przed zespołem bibliotecznym pozostaje ważne zadanie skatalogowania tych książek. Wypada dodać, źe przylegające do magazynu bibliotecznego pokoje sq skomputeryzowane i wyposażone w najnowocześniejsze urządzenia (skaner, drukarka, kserokopiarka itd.). Drugi komputer obsługuje pocztę internetową. Jeszcze jedna bardzo charakterystyczna rzecz zasługuje na podkreślenie, że ściany nie tylko kościoła ale innych omawianych pomieszczeń pokrywają obrazy o wysokim poziomie artystycznym. Wśród tych obrazów szczególną rolę spełniają dzieła wspomnianych na innym miejscu rumuńskich braci : Floriana i Krystiana Ungoreum. Należy życzyć tej wspólnocie monastycznej eremu S. Giorgio na Rocca di Garda. jak najszybszego rozwoju także personalnego, gdyż na to zasługuje ze wszech miar. 